\title{
The Effect of Corporate Social Performance (CFP) on Corporate Financial Performance (CFP) in SOE and Non-SOE Companies in Indonesia
}

\author{
Muhammad Fadiel Sinaga ${ }^{1}$, Junino Jahja ${ }^{2}$ \\ \{sinagafadiel@gmail.com ${ }^{1}$ \} \\ Universitas Indonesia, Indonesia ${ }^{1,2}$
}

\begin{abstract}
This study analyzes the relationship between Corporate Social Performance and Corporate Financial Performance in State-Owned Enterprise (SOE) and non-SOE companies in Indonesia. The issue of CSR in developing countries is still left behind compared to developed countries in Europe and America. Previous research has shown how CSP can affect CFP is quite positive. the extent of the influence of CSR on financial performance will be measured using regression analysis. This research is a quantitative study using the Ordinary Least Square (OLS) method. Our data sources consist of companies listed on the IDX and have an ESG rating from 2013-2017. Besides, it will be seen the influence of the government in market competition, especially regarding SOE companies. The results show that CSP has a weak influence on the company's financial performance in all samples. In the case of Indonesia, state ownership does not influence the effect of CSP on CFP. In third model, this research show that CSP has a significant negative effect on the competitive industry group, but in concentrated industry shows that CSP has no significant effect on CFP. This study shows different result from many previous studies. This study has limitations because only a few state-owned companies in Indonesia have listed, furthermore too many companies in Indonesia did not have ESG rating during 2013-2017.
\end{abstract}

Keywords: Corporate Social Performance, Corporate Financial Performance, StateOwned Enterprise, Market Competition.

\section{Introduction}

The development of company management has made CSR an important issue in seeing the credibility of a company. Ghillyer [1] defines CSR as an action of an organization that seeks to achieve social benefits above the maximum social benefit for its shareholders and the fulfilment of all its obligations. This definition indirectly describes the corporation that operates in a competitive business environment. Besides, company managers are committed to an aggressive growth strategy while complying with all legal obligations at all levels of government [2]. Hinson and Ndhlovu [3] see that CSR management in the global context has moved rapidly from planning and implementation to evaluation and supervision stages. CSR is then associated with the company's performance in the future.

Suto and Hitoshi [4] said that Corporate Social Performance (CSP) could be measured by looking back at the five dimensions of CSR relating to stakeholder positions from a CSR perspective. The five CSP matrix dimensions are Employee Relations (EMP), environmental 
preservation (ENV), social contributions (SC), firm security and product safety (SS), and internal governance and risk management (IG). However, the relationship between the two variables is also influenced by other variables that differ in each country due to regulatory factors and the existing political situation. Long, $\mathrm{Li}, \mathrm{Wu}$, and Song [5] tried to see the impact of the government's authority on the implementation of CSR in China. They combine the emerging political views into the dominant instrumental view to understand CSR in China. The article shows that companies can be strategically involved in CSR to be able to improve their financial performance as economic actors or use CSR to overcome social problems as political actors.

So far, research in Indonesia has only been limited to the influence of the two variables without involving aspects of state ownership and market competition. In addition, the CSR data used comes from ESG which has paid attention to all aspects in detail. So that in the future it is hoped that the role of the government in market intervention through SOE can be evaluated. Further research can also see the influence that exists from each industry, not only from market competition. Because in Indonesia the political influence of the government on the market is still quite large and the policies regarding CSR are not systematic enough to be able to increase company awareness in maintaining sustainability.

\section{Literature Review}

\subsection{Social-Economic Model of CSR}

This model has two main arguments regarding CSR. First comes from the orthodox paradigm group which states that the social responsibility of business is a one-dimensional activity. This paradigm is often raised by Friedman, this group believes that the policy of social improvement is only based on consideration of profit as the only criterion for assessing the efficiency of business operations [6]. This group ignores the fact that business is part of a larger society with responsibilities that reach beyond the profit perspective.

On the other hand, the second model group sees business as part of a social matrix that contributes to the social matrix for the welfare of society as a whole and supports that business is part of a larger society and has the responsibility of reaching beyond the perspective of looking for long-term benefits. $\mathrm{Zu}$ [7] see that there were four different quadrants in seeing this dimension.

- Classical View: This quadrant relates to the classical view that social responsibility does not have provisions to be able to generate maximum profit for the company.

- Social-Economic view: This quadrant represents a narrow view of CSR where adopting several levels of CSR will result in a net profit for the company in terms of, for example, being able to avoid expensive regulations, building good relationships with customers, relationships with good distributors and of course is a political connection. This quadrant focuses on the socioeconomic view in which the business can simultaneously carry out the dual function of maximizing profits and serving social demand.

- Modern view: The perspective of this quadrant believes more, that business maintains its relationship with the broader community matrix where there are benefits that will flow from CSR actions in the long term and the short term.

- Philanthropic view: this quadrant represents a broader view of the SCR in which the business agrees to participate in charitable activities even though this is considered a "net 
cost". This impulse comes from altruistic feelings (prioritizing the interests of others) or ethics to do good for society.

\subsection{Relationship between CSP and CFP}

Previous research on the relationship between CSP and CSR has produced several theories. The instrumental stakeholder theory focuses on the relationship between stakeholder contracts and the belief that stakeholders (claims to improve CSR) contribute to the company's main objectives [8].Trade-off Theory shows a negative relationship between CSR and CFP. The main reason is that CSR will only increase spending and reduce profits. This theory is a neoclassical theory which is currently not much discussed in discussions about CSR [9]. Slack Resources Theory considers that a good CFP condition in a company will increase access to financial resources. So then CSR can be enhanced by investing the funds they have for social interests, such as relations with workers, communities and society or the environment [9].Managerial Opportunism Hypothesis sees that a good CFP condition does not make the company carry out activities to improve CSR. A good CFP is actually used to make as much investment as possible [10].

Literature review on the relationship between CSP and CFP study indicates that there are positive relations about the CSP attributes in effect to the Firm's financial performance. Busch and Friede [11] explain that CSP-CFP has a positive impact, whether firms focus on ecological or social aspects, through corporate reputation turns out to be a key CSP determinant. Lin, Hung, Chou, and Lai [12] in Taiwan also showed the positive effect of CSP on financial performance. The research uses the CSR Hub index by paying attention to the geographical and industrial aspects of the company. But, some studies show that CSP-CFP has a weak relationship. McWilliams and Siegel [13] show that CSR has a neutral impact on the financial performance of the company. The research shows that investment in R\&D is very significant in improving company performance. Wang and Sarkis [14] have taken data on the 500 largest companies in America during the period 2009-2013 showing the small impact of CSR on the company's financial performance. CSR can have further influence when CSR is carried out focused on efforts to increase company revenue. In addition to the United States, research on the impact of CSR on CFP has begun to be carried out in many Asian countries.

This study uses an index created by ESG Bloomberg because ESG data is considered to have several advantages compared to other databases regarding CSR. First, ESG uses the most comprehensive methodology to evaluate corporate governance, social and environmental activities. The ESG database began to be built by the Bloomberg ESG Group in early 2008 . Second, the Bloomberg ESG database provides detailed scores on a scale of 0-1000 in each environmental, social and governance category. Examples are Coca-Cola has an environmental value of 41.33 , social 31.00 and governance 62.5. The Bloomberg Team believes that ESG can provide investors with a macro-level assessment of how companies manage their ESG so that it can be integrated into their fundamental analysis.

This study determines relations between CSP-CFP using the Regression Method that also used by [5]. Their study tried to see the impact of the government's influence on the implementation of CSR in China. They combine the emerging political views into the dominant instrumental view to understand CSR in China. The article shows that companies can be strategically involved in CSR to be able to improve their financial performance as economic actors or use CSR to overcome social problems as political actors.

This study uses the same variable and model to test the hypothesis in Indonesia. The combination of the institutional and political perspectives of CSR enables us to better understand CSR practices rather than applying these perspectives separately. Companies can 
use CSR strategically to differentiate themselves and to improve their financial performance. Long et al [5] show that non-SOE companies can use CSR to add value to companies, this strategy is very effective for those operating in highly competitive industries. Although stateowned companies have the advantage of obtaining government-controlled resources and enjoy preferential treatment because of their inherent connections to the government, CSR continues to play an increasingly important role in improving financial performance when the competition is intensified.

\section{Research Methods}

This research uses the Ordinary Least Square (OLS) method. Most of the empirical analysis in management research uses linear regression models. The aim is to present coefficient estimates and statistically assess significance. Independent variables with statistically significant coefficients are said to affect the dependent variable. The general view that can be held is that the estimated coefficient captures how the independent variable influences the dependent variable. The data obtained from the results of subsequent studies were analyzed with multiple linear regression analysis models using the help of Eviews 4.0. Before a multiple regression analysis is performed, author make Classic Assumptions Test, which are the Normality, Multicollinearity, Heteroscedasticity, and Autocorrelation Tests.

Observation data were obtained from companies that had a CSP rating from the ESG Score Rating for the 2013-2017 period. Information about the rating from ESG is very important to be able to see the effect of CSP on the company's financial performance. In the case of Indonesia, there were only 32 Indonesian companies that were on the Indonesia Stock Exchange and had an ESG score during the 2013-2017 period. The 32 companies include SOE and Non-SOE companies from various industries. In addition, the financial data of selected companies will also be collected through Tomson Reuters.

The variables used in this study were divided into three categories: the dependent variable, the independent variable, and the control variable [15]. The dependent variable used is ROA as a reference to assess the financial performance of the selected company. ROA is seen from the total net income divided by the total assets of the company. The independent variables used in this study are Corporate Social Performance, HHI index and the Effect of State Ownership which are calculated with dummy variables. In addition, this study also uses four control variables namely firm size by looking at the Logs of Total Assets, Leverage by calculating total liabilities divided by total company assets, sales growth is calculated by looking at the company's revenue growth each year and Firm Age seen by how long the company operates in the current industry.

Based on the data above, this study uses three models to be able to see the results of the hypotheses that have been submitted. The three models are:

$\mathbf{R O A t}+\mathbf{1}=\alpha \mathrm{p} \beta 1 \mathrm{CSPt}+\sum \beta \mathrm{k}$ Control variablet $+\epsilon \mathrm{t}:$

ROAt $+1=\alpha$ p $\beta 1$ CSPt $+\beta 2$ State ownershipt $+\beta 3$ CSPt $\times$ State ownershipt $+\sum \beta \mathrm{k}$ Control variablet $+\epsilon \mathrm{t}$ :

$\mathbf{R O A t}+1=\alpha p \beta 1 \mathrm{CSPt}+\beta 2$ Industry competitiont $+\beta 3 \mathrm{CSPt} \times$ Industry competitiont $+\sum \beta \mathrm{k}$ Control variablet $+\epsilon t$ 
Where:

$\begin{array}{ll}\text { ROA } & =\text { Return on Asset } \\ \text { CSP } & =\text { Corporate Social Performance (ESG) } \\ \text { State Ownership } & =\text { Dummy variable } \\ \text { Industry Competition } & =\text { Herfindahl-Hirschman Index }\end{array}$

After modelling the data and getting the estimated parameters, statistical testing to be performed are the parameters significance testing, the goodness of fit model testing, and the overdispersion model testing. After all experiments have been completed, the expected estimation is that CSR performance affects the company's finances. In addition, the role of the government in the intervention of SOE companies also makes a good CSR evaluation of SOEs even though they do not have a good enough impact on the company's financial performance.

\section{Results and Discussion}

\subsection{Descriptive Statistics}

From the statistical results, it can be seen how the average of the variables used and see the most significant and smallest values of the data taken and the average and standard deviation to see the normality of the data to be used. With a total of 160 observations, the samples taken were those listed from the public financial statements with complete information for five years.

Table 1. Statistic Descriptive

\begin{tabular}{lcccccccc}
\hline & \multirow{2}{*}{ ROA } & CSP & SO & HHI & SIZE & $\begin{array}{c}\text { Growth } \\
\text { Sales }\end{array}$ & Leverage Firm Age \\
\hline Mean & 0.095642 & 52.95884 & 0.281250 & 2125.557 & 17.71795 & 0.094403 & 0.545125 & 38.68750 \\
Median & 0.059471 & 58.16480 & 0.000000 & 1357.285 & 17.38527 & 0.082629 & 0.531540 & 39.00000 \\
Maximum & 0.457885 & 91.00000 & 1.000000 & 6148.167 & 20.84322 & 1.106197 & 1.266055 & 81.00000 \\
Minimum & -0.050124 & 12.70347 & 0.000000 & 524.2017 & 14.89286 & -0.277242 & 0.133061 & 9.000000 \\
Std. Dev. & 0.106187 & 18.31310 & 0.451021 & 1371.528 & 1.362194 & 0.163742 & 0.224727 & 15.91138 \\
\hline \multicolumn{1}{c}{ Obs. } & 160 & 160 & 160 & 160 & 160 & 160 & 160 & 160 \\
\hline
\end{tabular}

Table 2. Serial Correlation Test Tables

\begin{tabular}{cccccccc}
\hline & CSP & HHI & SO & Leverage & Size & $\begin{array}{c}\text { Growth } \\
\text { Sales }\end{array}$ & Firm Age \\
\hline CSP & 1.000000 & & & & & & \\
HHI & -0.016826 & 1.000000 & & & & & \\
\hline SO & 0.366105 & -0.056749 & 1.000000 & & & & \\
Leverage & 0.015865 & 0.179628 & 0.174762 & 1.000000 & & & \\
Size & 0.340480 & -0.010576 & 0.392317 & 0.511211 & 1.000000 & & \\
Growth Sales & -0.054352 & 0.067583 & 0.216724 & 0.220167 & 0.082143 & 1.000000 & \\
Firm Age & 0.356388 & 0.257633 & 0.223525 & 0.081422 & 0.255478 & 0.022097 & 1.000000 \\
\hline
\end{tabular}

If we look at the results of the correlation tables that have been tested, it can be seen that the correlation coefficient between the independent variables does not have an enormous 
enough value. The highest value is 0.6252 , and it does not reach 0.7 [16]. By looking at the results of the table above, we can conclude that this model does not have multicollinearity. This is because the correlation coefficient between independent variables is still under the condition of multicollinearity, which is 0.8 [17].

\subsection{Regression Results}

Because we use panel data for the period 2013-2017 in this study, we perform the Hausman test to determine an appropriate regression model. The results from the pooled ordinary least square (OLS) and fixed-effect models indicate that $p$ is .000. Which suggest that the fixed-effects model is more favorable. The results for fixed and random-effects models show that $p=0.3008$ and $p=0.5208$. This result suggests that the random-effects is more favorable. As a result, we use the fixed-effects model in this study.

Table 3. Relationship between CSP and financial performance

\begin{tabular}{clc}
\hline Variable & & All Sample \\
\hline \multirow{2}{*}{ CSP } & Coef. & -0.939415 \\
& Prob. & 0.3490 \\
\hline \multirow{2}{*}{ Size } & Coef. & -4.489502 \\
& Prob. & 0.0000 \\
\hline \multirow{2}{*}{ Growth Sales } & Coef. & 2.057599 \\
& Prob. & 0.0413 \\
\hline \multirow{2}{*}{ Leverage } & Coef. & 0.208302 \\
& Prob. & 0.8353 \\
\hline \multirow{2}{*}{ Firm Age } & Coef. & 1.870133 \\
& Prob. & 0.0634 \\
\hline
\end{tabular}

Based on the data in the table 3, the relationship between CSP and CFP in previous studies has shown a positive effect. This means that the quality of the company's social performance will significantly affect the company's financial performance. However, in this study it can be seen that the effect of CSP on CFP is not significant. Based on the regression results, the probability p-value is 0.3479 for all companies. The coefficient value also has a negative number, namely 0.939415 .

Table 4. Relationship between CSP and financial performance in SOE and Non-SOE

\begin{tabular}{clcc}
\hline Variable & & Non-SOE & SOE \\
\hline \multirow{2}{*}{ CSP } & Coef. & 0.17422 & -2.00214 \\
& Prob. & 0.8620 & 0.0523 \\
\hline \multirow{2}{*}{ Size } & Coef. & -4.75907 & 0.45474 \\
& Prob. & 0.0000 & 0.6518 \\
\hline \multirow{2}{*}{ Growth Sales } & Coef. & 0.39013 & 2.63334 \\
& Prob. & 0.6972 & 0.0121 \\
\hline \multirow{2}{*}{ Leverage } & Coef. & 0.88489 & -2.9886 \\
& Prob. & 0.3782 & 0.0048 \\
\hline \multirow{2}{*}{ Firm Age } & Coef. & 1.84186 & -0.30669 \\
& Prob. & 0.0682 & 0.7607 \\
\hline
\end{tabular}


Table 5. Relationship between CSP and financial performance and the moderating effect of state ownership

\begin{tabular}{clc}
\hline Variable & & All Sample \\
\hline \multirow{2}{*}{ CSP } & Coef. & -0.422892 \\
& Prob. & 0.673 \\
\hline \multirow{2}{*}{ CSP x SO } & Coef. & -0.624835 \\
& Prob. & 0.533 \\
\hline \multirow{2}{*}{ SO } & Coef. & 0.324648 \\
& Prob. & 0.7459 \\
\hline \multirow{2}{*}{ Size } & Coef. & -4.159286 \\
& Prob. & 0.0001 \\
\hline \multirow{2}{*}{ Growth Sales } & Coef. & 2.114719 \\
& Prob. & 0.0361 \\
\hline \multirow{2}{*}{ Leverage } & Coef. & 0.260202 \\
& Prob. & 0.7951 \\
\hline \multirow{2}{*}{ Firm Age } & Coef. & 1.733732 \\
& Prob. & 0.085 \\
\hline
\end{tabular}

Based on the regression results from the first model with a sample of BUMN and NonBUMN companies, there are differences in the results in the influence between CSP and ROA. For non-BUMN companies, the p-value is 0.8620 , which indicates that there is no significance between the CSP variable and ROA. Whereas in BUMN companies the probability of p-value shows the number $0.0523(<10 \%)$ which indicates that there is a significant influence between CSP and ROA in SOE companies. CSP has a negative effect when viewed from the coefficient value, namely -2.00214 . This shows that CSP negatively affects the profitability of SOE companies. Which is if the company improves their CSR performance, it will reduce the level of profitability. This condition shows that the theory of trade-off is proven in the case of SOE in Indonesia. This cannot be separated from the function of SOE which is also a service, so that profit is not the only goal of companies such as Non-SOE companies. SOE will tend to continue to have a social impact on society without paying too much attention to the profitability of their company.

Table 6. Relationship between CSP and financial performance and the moderating effect of industry competition

\begin{tabular}{clc}
\hline Variable & & All Sample \\
\hline \multirow{2}{*}{ CSP } & Coef. & 1.339831 \\
& Prob. & 0.1823 \\
\hline \multirow{2}{*}{ HHI Competitive } & Coef. & 2.430617 \\
& Prob. & 0.0163 \\
\hline \multirow{2}{*}{ HHI Less Competitive } & Coef. & 0.806674 \\
& Prob. & 0.7459 \\
\hline \multirow{2}{*}{ CSP X HHI Competitive } & Coef. & -2.178176 \\
& Prob. & 0.031 \\
\hline \multirow{2}{*}{ CSP X HHI Less Competitive } & Coef. & -0.612452 \\
& Prob. & 0.5412 \\
\hline \multirow{2}{*}{ Size } & Coef. & -4.159286 \\
& Prob. & 0.0001 \\
\hline
\end{tabular}




\begin{tabular}{clc}
\hline \multirow{2}{*}{ Growth Sales } & Coef. & 2.114719 \\
& Prob. & 0.0361 \\
\hline \multirow{2}{*}{ Leverage } & Coef. & 0.260202 \\
& Prob. & 0.7951 \\
\hline \multirow{2}{*}{ Firm Age } & Coef. & 1.733732 \\
& Prob. & 0.085 \\
\hline
\end{tabular}

Based on the results of the third regression model for all sample companies, industrial competition affects the company's financial performance, especially in more competitive industries. The probability of $\mathrm{p}$-value in this variable shows the number 0.0163 with a coefficient of 2.430617, which means that there is a positive significance between industrial competition and financial performance as measured by ROA. Meanwhile, the variable that combines industrial competition and CSP shows a probability p-value of 0.031 and a coefficient of -2.178176 . This condition shows that in a more competitive industry, CSP actually gives negative significance to the company's ROA.

\subsection{Discussion}

The relationship between CSP and CFP in previous studies has shown a greater impact. This means that the quality of corporate social performance will significantly affect the company's financial performance [18]. The results of the research in the first model of research tend to support the old theory of the relationship between CSP and CFP, namely the trade-off theory which states that corporate social performance is negatively related to the company's financial performance. This theory sees that social activities only spend money owned by companies without clear benefits, even though the funds owned can be used to be able to make investments and increase company income. In addition, the data in Indonesia also relates to the theory of slack resources which sees that companies that have good financial performance will actually give birth to good social performance and vice versa.

The results of this first hypothesis study also show different results from Long et al. [5] In research conducted in China, it can be seen that the CSP has a greater impact to the company's financial performance. Long et al. [5] in their study used a sample of 2218 companies from all over China. The number of samples differed quite significantly from the data available in Indonesia, which was 32 companies.

The results in the second model of this study show a negative relationship of the effect of state ownership on the relationship between CSP and CFP. This hypothesis certainly cannot be separated from the first hypothesis which shows the negative impact between CSP and CFP on all existing samples. Long [5] sees that social performance will have a more positive impact on companies that are not owned by the state. The first reason is that social performance is often used as a tool to gain political legitimacy and also the resources of the state. So that private companies need efforts to get it by continuing to improve their CSR. Whereas SOE companies no longer need these efforts because they are companies that are directly owned by the government as political authorities and also have access to government owned resources.

Long et al. [5] considers that in industries that have higher competition tends to increase the relationship between CSP and CFP. This study is different from the findings of Lev et al. [18] which shows that American companies in the financial sector and retail have a positive influence on their CSP and CFP relationships. In this study, it can be seen that the influence exerted by CSP on the company's financial performance is negatively related. This means that the increase in social performance carried out by companies in this industry has a negative 
impact on company profitability. This condition tends to support the trade-off theory which is a classic theory that is rarely found in previous research.

\section{Conclusion}

Based on the results of research and analysis that has been done, then some conclusions can be drawn. First, the company's CSR performance which is measured using a rating from ESG shows no significance to the ROA of both SOE companies and non-SOE companies. This is not in line with research conducted by Long et al. [5]. This condition shows that CSR in Indonesia in general has not been able to affect the performance of companies, especially in terms of profitability. Firm profitability tends to be influenced by other factors, the research can be seen from several control variables such as Size can Growth Sales which shows a positive effect on company ROA.

Second, the effect of corporate CSR performance on financial performance in SOE and non-SOE companies is not much different. This means that state ownership has no impact on companies' efforts to increase their profitability through increased CSR. SOE companies basically have various CSR programs that are specifically regulated by the Law so that SOE companies' CSR reports tend to be better.

Third, the effect of CSR performance on company financial performance shows a negative effect on industries that have high competition. Meanwhile, industries that tend to be concentrated have no effect. This condition shows that companies in an industry with a high level of competition will actually experience a decrease in profitability if they take CSR actions. Industries that have a high level of competition tend to be industries that use consumers as their source of income, not companies that have major government partners or between companies. Companies in a competitive industry should be able to use CSR as a source of their promotion, but in reality, in Indonesia this cannot be in line as in previous studies.

\subsection{Research Limitations}

This study has several limitations, first, not all companies in Indonesia have had ESG data since 2013, thus creating limited companies that can be sampled. Second, the period used in this study is only 5 years ago because before 2013 the companies that have ESG under 32 companies. Third, Indonesia has only a handful of state-owned companies listed on the stock exchange.

\section{References}

[1] A. Ghillyer, Business Ethics Now. Boston: McGraw-Hill, 2013.

[2] M. Hopkins, Conceptualising Corporate Social Responsibility (CSR) and Corporate Social Investment (CSI). New York: Earthscan Publications Ltd, 2007.

[3] R. E. Hinson and T. P. Ndhlovu, "Conceptualising Corporate Social Responsibility (CSR) and Corporate Social Investment (CSI),” South African Context. Soc. Responsib. J., pp. 332-346, 2011.

[4] M. Suto and T. Hitoshi, Corporate Social Responsibility and Corporate Finance in Japan. Tokyo: Springer, 2018.

[5] W. Long, S. Li, H. Wu, and X. Song, "Corporate social responsibility and financial performance: The roles of government intervention and market competition," Corp. Soc. 
Responsib. Environ. Manag., 2019.

[6] A. M. Quazi and D. O. Brien, "Cross-national model of CSR," J. Bus. Ethics, vol. 25, pp. 33$51,2000$.

[7] L. Zu, Corporate Social Responsibility, Corporate Restructuring and Firm's Performance: Empirical Evidence from Chinese Enterprises. Heidelberg: Springer, 2009.

[8] T. M. Jones, "Instrumental Stakeholder Theory: A Synthesis of Ethics and Economics," Acad. Manag. Rev., vol. 20, pp. 404-437, 1995.

[9] S. A. Waddock and S. B. Graves, "The Corporate Social Performance-Financial Performance Link," Strateg. Manag. J., vol. 18, no. 4, pp. 303-319, 1997.

[10] L. E. Preston and D. P. O'Bannon, "The Corporate Social-Financial Performance Relationship a Typology and Analysis,” Bus. Soc., vol. 36, pp. 419-429, 1997.

[11] T. Busch and G. Friede, "The Robustness of the Corporate Social and Financial Performance Relation: A Second-Order Meta-Analysis," Corp. Soc. Responsib. Environ. Manag., vol. 25, no. 4, pp. 583-608, 2018.

[12] L. Lin, P.-H. Hung, D.-W. Chou, and C. W. Lai, "Financial performance and corporate social responsibility: Empirical evidence from Taiwan," Asia Pacific Manag. Rev., vol. 24, no. 1, pp. 61-71, 2019.

[13] A. McWilliams and D. Siegel, "Corporate social responsibility and financial performance: Correlation or misspecification?," Strateg. Manag. J., vol. 21, pp. 603-609, 2000.

[14] Z. Wang and J. Sarkis, "Corporate social responsibility governance, outcomes, and financial performance,” J. Clean. Prod., vol. 162, pp. 1607-1616, 2017.

[15] U. Sekran and R. Bougie, Research Methods for Business: A Skill-Building Approach. United Kingdom: Wiley and Sons Ltd, 2016.

[16] Ariefianto and D. Moch, Ekonometrika: Esensi dan Aplikasi dengan Menggunakan EViews. Jakarta, 2012.

[17] D. N. Gujarati and D. C. Porter, Basic Econometric (Edisi Kelima). Singapore: McGraw-Hill, 2008.

[18] B. Lev, C. Petrovits, and S. Radhakrishnan, "Is doing good good for you? how corporate charitable contributions enhance revenue growth," Strateg. Manag. J., 2009. 